Creative Commons User License: CC BY-NC-ND

Abstracted by: EBSCOhost, Electronic Journals Service (EJS), Google Scholar, Journal Seek, Scientific Commons,

Food and Agricultural Organization (FAO), CABI and Scopus

http://eoi.citefactor.org/10.11226/v23i2
Journal of Agricultural Extension

Vol. 23 (2) April, 2019

ISSN(e): 24086851; ISSN(Print); 1119944X

http://journal.aesonnigeria.org

http://www.ajol.info/index.php/jae

Email: editorinchief@aesonnigeria.org

\title{
Farm and Non-Farm Income Diversification Activities among Rural Households in Southeast, Nigeria
}

https://dx.doi.org/10.4314/jae.v23i2.12

\section{Odoh, Ngozi Ekunyi}

Department of Agricultural Economics, Management \& Extension, Ebonyi State University, P.M.B 053, Abakaliki, Ebonyi State, Nigeria

Email: ekunyiodoh@yahoo.com; +2348063633634

\section{Nwibo, Simon Uguru}

Department of Agricultural Economics, Management \& Extension, Ebonyi State University, P.M.B 053, Abakaliki, Ebonyi State, Nigeria

Email: sunwibo92@gmail.com; +2347033210710

\section{Eze, Anayochukwu Victor}

Department of Agribusiness Management \& Trade, Kenyatta University, Kenya

Email: ezeanayochukwu09@gmail.com; +2348036718919

\section{Igberi, Christiana Ogonna}

Department of Agriculture (Agricultural Economics and Extension Programme), Alex Ekwueme Federal University Ndufu-Alike Ikwo, PMB 1010, Abakaliki, Ebonyi State, Nigeria

Email: igberitina@yahoo.com; +2347031161051

\section{Abstract}

The study assessed farm and non-farm income diversification activities among rural households in Southeast, Nigeria. Purposive and multi-stage random sampling techniques were used to collection data from three hundred and sixty (360) rural households using structured interview schedule. Means, percentage and frequency count were used to analyse the objectives of the study. The result showed that 82.5 $\%$ of rural households diversified their income sources into other non-farm activities as against $17.5 \%$ that depended solely to farm activities. Further analysis indicated that $64.4 \%$ of the rural households engaged in crop production, $46.9 \%$ practiced livestock production, $5 \%$ were into collection of forestry products, $13.1 \%$ engaged in farm products processing while $23.3 \%$ engaged in storage and marketing of agricultural products. However, the various non-farm activities diversified into by the households were: petty trading (53.53\%), storage and marketing of agricultural commodities (31.31\%), sale of landed property (15.82\%), agricultural wage labour (16.84 \%) and hire purchase (9.09\%). Others included rental services (19.52\%), transportation (example taxis, motorcycle and tri-cycle business) (21.21\%), craftsmanship (13.46 \%) and civil/public service jobs (28.28\%). The study recommended that government should improve rural infrastructures like good road network, electrification, potable water, telecommunication service, and affordable healthcare system since they are important for enhancing socio-economic activities. It is also recommended that government should initiate policy for reducing risk and uncertainties inherent in agricultural activities in order to encourage farmers to remain in the business of farming.

Keywords: Diversification, economic activities, rural households, livelihood, South East Nigeria 
Creative Commons User License: CC BY-NC-ND

Abstracted by: EBSCOhost, Electronic Journals Service (EJS),

Google Scholar, Journal Seek, Scientific Commons,

Food and Agricultural Organization (FAO), CABI and Scopus
Journal of Agricultural Extension

Vol. 23 (2) April, 2019

ISSN(e): 24086851; ISSN(Print); 1119944X

http://journal.aesonnigeria.org

http://www.ajol.info/index.php/jae

Email: editorinchief@aesonnigeria.org

\section{Introduction}

Nigeria is mainly characterised by rural settlement with high poverty index (Olowa, 2012). To this effect, agricultural activity remains the major occupation of the people. However, agriculture alone cannot reduce the high level of poverty; hence, non-farm activities are equally imperative. In many instances, expansion in rural non-farm employment is very much linked to expansion in agricultural sector because agricultural sector remains the largest supplier of intermediate production inputs to other economic sectors (Briones, 2017). Odoh (2015) opines that agriculture influences non-farm activity because farm labour can be deployed to non-farm sector for production, processing, distribution and marketing. However, as globalization and urbanization proceed, expansion in rural non-farm sector continues to rise independent from agriculture (FAO, 2017). In the light of the foregoing, Estruch and Grandelis (2013) proposes an integrated approach for promoting farm and non-farm activities that will foster a more viable rural sector. Recent development resulting from the change in the socioeconomic, political environment and the climate conditions in Nigeria just as in many less developed nations of the world have worsened the living conditions of many rural households, prompting rural dwellers to switch over to alternative economic activities as a risk minimization strategy.

The risk minimization motive of income diversification was justified by Benmehaia and Brabez (2016) that if the profits from agricultural activities are negatively correlated with each other, it is possible to reduce the variability (risk) of total income by diversifying the risk to various non-farm activities. Income diversification remains a strategy employ by households to minimise income variability and guarantee potential high income level (Dev, Sultana and Hossain, 2016). Diversification entails the appropriation of production assets among several farm and non-farm income generating activities. According to Wan, Li, Wang, Liu and Chen (2016), diversification refers to the process of creating multiple income sources. In furtherance, the authors maintain that the number of income sources available to farm household at a particular point in time determines the income diversity, whereas the difference in the number of income sources available to a household at a different point in time shows the level of income diversification of the household over the corresponding time. Consequently, households having several income sources are considered as those with higher levels of income diversity. Hence, increasing the number of income sources available to households, overtime leads to increased diversification over time.

Studies indicate that diversification is strategically important to rural communities in Africa (Odoh and Nwibo, 2016; Dev et al., 2016). Khatiwada et al. (2017) submit that many of these studies have suggested that historically, large proportion of rural households have diversified their productive assets to accommodate wide range of other economic activities. Meanwhile, there has been increasing empirical evidence that the majority of Africans have diversified their livelihood sources, both on-farm (crop, livestock, fisheries) and off-farm activities or market and non-market activities, as a strategy for mitigating risks inherent in unpredictable agro-climatic and sociopolitical economic environment (Odoh and Nwibo, 2016; Dev et al., 2016).

Diversification is thus a rational households' response to lack of opportunities for specialisation, which is initially not considered as most favourable choice. To this end, Maniriho and Nilsson (2018) inferred that rural farming households have been found to diversify their income sources thus, allowing them to spread risk and enhance income generation. This is often necessary in agriculture-based peasant economies like in Southeast Nigeria where risks such as variability in soil quality, pests and diseases, price shock, unpredictable rainfall, flood and erosion menace and 
Creative Commons User License: CC BY-NC-ND

Abstracted by: EBSCOhost, Electronic Journals Service (EJS), Google Scholar, Journal Seek, Scientific Commons,

Food and Agricultural Organization (FAO), CABI and Scopus
Journal of Agricultural Extension

Vol. 23 (2) April, 2019

ISSN(e): 24086851; ISSN(Print); 1119944X

http://journal.aesonnigeria.org

http://www.ajol.info/index.php/jae

Email: editorinchief@aesonnigeria.org

http://eoi.citefactor.org/10.11226/v23i2

other weather related events have led to low productivity and invariably low income, and which continually trap rural households in a vicious cycle of poverty. However, recent studies have shown that instead of emphasizing specialisation within existing portfolios, upgrading them to increase income could be a more realistic approach that will be more appropriate for poverty reduction (Alkire, Apablaza and Jung, 2014; Williams, 2016). A growing literature on livelihood diversification across the developing world has pointed to the increasing role of non-farm incomes in poverty reduction (Odoh and Nwibo, 2016). Despite these studies, it appears there is paucity of empirically documented studies on farm and non-farm income diversification activities of rural households in Southeast, Nigeria, hence, the need for this study. In order to address this problem, the study set out to address the following research questions; what are the primary economic activities of rural households? What are characteristics of the non-farm activities of the rural households in the area?

Specifically, the objectives were to:

- determine the primary economic activities of rural households; and

- characterise the non-farm activities of the rural households in the area.

\section{Methodology}

The study area was Southeast, Nigeria. The area is comprised of five states, namely; Ebonyi, Enugu, Anambra, Imo, and Abia. According to National Population Census of 2006, Southeast Nigeria has a total population of 16.4 million people. With an approximated landmass of 58,214.7 sq. km; the area lies between longitude $6050 \mathrm{l}$ and $8030 \mathrm{I} \mathrm{E}$ and latitude $40 \mathrm{30l}$ and $705 \mathrm{I} \mathrm{N}$. Southeast Nigeria is bordered in the east by Cross-River State, in the west by Delta and River States, in the north by Benue and Kogi States, and in the south by Rivers and Akwa-lbom States. Situated within the rainforest and derived savannah regions of the country, Southeast Nigeria is characterised by two major seasons: the rainy season which last from April to October with July and September as peaks, and the dry season that starts from November and lasts till March. Atmospheric temperature in the area varies from $180 \mathrm{C}$ to $340 \mathrm{C}$ within the year. The people of the area are predominantly smallholder farmers growing mainly arable crops like; yam, cassava, maize rice, cocoyam, potato, and few plantation crops like palm tree and cashew. Apart from being agriculturally endowed, the people are into trades and commerce.

The study adopted multistage and purposive sampling techniques for the selection of respondents. The choice of purposive sampling technique was to select states that are more agrarian and to avoid picking states that are contiguous to each other. Three states of Abia, Anambra and Ebonyi were purposively selected from the five states of Southeast, Nigeria. According to ADP record, the selected States have a total of eight thousand, three hundred and forty $(8,340)$ registered farm households in the following order: Abia - two thousand one hundred $(2,100)$; Ebonyi - four hundred and forty $(4,440)$; and Anambra - one thousand eight hundred $(1,800)$.

Furthermore, three agricultural zones in each state were purposively selected to give a total of nine (9) agricultural zones. From each of the nine (9) agricultural zones two extension blocks were randomly selected to give a total of 18 Blocks. From each of the selected blocks, two (2) circles were randomly selected to give a total of thirty (36) circles. From the 36 circles, ten (10) farming households each were randomly selected. Thus, a total of three hundred and sixty (360) farming households were used for the study. Primary data were collected using structured questionnaire administered as interview to each of the household heads. Both descriptive and inferential 
Creative Commons User License: CC BY-NC-ND

Abstracted by: EBSCOhost, Electronic Journals Service (EJS), Google Scholar, Journal Seek, Scientific Commons,

Food and Agricultural Organization (FAO), CABI and Scopus
Journal of Agricultural Extension

Vol. 23 (2) April, 2019

ISSN(e): 24086851; ISSN(Print); 1119944X

http://journal.aesonnigeria.org

http://www.ajol.info/index.php/jae

Email: editorinchief@aesonnigeria.org

http://eoi.citefactor.org/10.11226/v23i2

statistics were employed to actualize the objectives of the study. Specifically, objectives (i) and (ii) were analysed using descriptive statistics.

\section{Results and Discussion}

\section{Economic Activities Engaged in by Farm Households in Southeast Nigeria}

The nature of economic activities engaged in by the rural households in South-East Nigeria shows that the majority of them (82.5\%) diversified their income sources into other non-agricultural activities while only $17.5 \%$ limited their economic activities solely to agricultural production (Table 1). The vast proportion of farmers that diversified into other economic activities can be ascribed to the limited land mass in South East Zone of Nigeria with the population competing for the little available arable land. Furthermore, Obinna and Onu (2017) opined that the meager income derived from farm enterprises compels households in rural African societies to engage in non-farm activities to supplement income, in order to lessen risk inherent in income from agricultural activities. He went ahead to explain that in places with limited land, the non-farm activities serve as vital economic option for the poor rural households.

Furthermore, Nagler and Naudé (2017) was of the view that the upsurge in non-farm activities is probably due to the renew level of development in rural areas of Nigeria particularly since the advent of democratic governance in 1999, which has brought about significant transformation in social amenities in several rural areas. This has provided favourable economic conditions that increase entrepreneurship opportunities in the rural areas. Consequent upon this, it is sufficing to say that diversification is designed to reduce risk inherent in agriculture as a result of unpredictable climate conditions and incidence of pest and diseases. Seasonal variation in farm production is another risk factor in agricultural activities mainly due to the rain-fed depended nature of Nigerian agriculture. This phenomenon compels farmers to engage in non-farm activities, thereby, suggesting a declining proportion of households who depends solely on farming activities for livelihood and increasing number of households who combined farm and non-farm activities in the study area. The finding suggests that highly to moderately susceptible households combine both farm and non-farm activities so as to ensure steady income flow.

Table 1: Categorization of the rural households into economic activities

\begin{tabular}{ll}
\hline Activities & Percentage $(\mathrm{n}=360)$ \\
\hline Farm alone & 17.5 \\
Diversified non-farm & 82.5 \\
\hline
\end{tabular}

From the analysis in Table 2, $64.4 \%$ of the rural households are engaged in crop production, 46.9 $\%$ practice only livestock production, $5 \%$ are involved in collection of forest products, $13.1 \%$ are involved in agricultural products processing while $23.3 \%$ are into storage and marketing of agricultural products. However, individual analysis of these activities reveals that under crop production, $88.7 \%$ of the households are involved in rice production, $71.6 \%, 64.2 \%, 10.3 \%$ and $2.6 \%$ are into cassava production, yam production, maize cultivation and cocoyam production respectively. From the analysis, it was observed that rice, cassava, and yam are the major crops produced in the area. 
Creative Commons User License: CC BY-NC-ND

Abstracted by: EBSCOhost, Electronic Journals Service (EJS), Google Scholar, Journal Seek, Scientific Commons,

Food and Agricultural Organization (FAO), CABI and Scopus
Journal of Agricultural Extension

Vol. 23 (2) April, 2019

ISSN(e): 24086851; ISSN(Print); 1119944X

http://journal.aesonnigeria.org

http://www.ajol.info/index.php/jae

Email: editorinchief@aesonnigeria.org

http://eoi.citefactor.org/10.11226/v23i2

Analysis of the livestock sector shows that $98.7 \%$ of the rural households in the area kept small ruminants like sheep and goat, $31.2 \%$ keep poultry, $27.3 \%$ are into fishery production while 11.0 $\%, 7.1 \%$ and $0.6 \%$ rear cattle, piggery and rabbits respectively. Thus, small ruminants, fishery and poultry production constitute the major livestock produced in the area. Livestock activities provide alternative source of income (savings) as well as protection against crop income failure. This corroborates the finding of Igwe (2013) that only about $45 \%$ of rural households in Ebonyi State kept livestock. According to him, these livestock which were kept for traditional and customary reasons also serve as a form of savings and contingency funds particularly due to the non-existence of formal credit institutions in the rural areas.

Analysis of the number of those engaged in the collection of forest products shows that $66.9 \%$ of the households engage in vegetable collection or gathering, $50 \%$ are into the sales of fire wood, $27.8 \%$ and $16.7 \%$ engage in the collection of medicinal leaves and ropes respectively. Hence, gathering of forest vegetable and firewood for sale were the major forestry activities engaged by the smallholder households in the area. The result also showed that rural households in SouthEast Nigeria engage in the collection of forest products and natural resources.

Individual analysis of the agricultural products processed by the households indicates that $53.3 \%$ of the farmers processed cassava, $42.5 \%$ engaged in paddy rice processing while $27.7 \%$ and 17 $\%$ engaged in the processing of palm produce and legumes respectively. This result therefore indicates that processing of cassava and paddy rice grains are the major processing activities of the households in the area. Off-farm processing activities and petty trading provide the households the most viable options for non-farm employment in the study area. Farm processing activities include preparation of rice, cassava, palm oil and wild fruits so as to produce more suitable products which are either sold for income or consumed by household members. Rural areas also offer non-farm activities such as: basket weaving, broom, poultry, palm wine and traditional medicine.

Analysis of storage and marketing of agricultural products indicates that $60.7 \%$ of the households engage in the storage and marketing of grains while $54.8 \%$ are into roots and tubers as $29.5 \%$ and $7.1 \%$ engage in nuts and legumes and marketing of palm products respectively. Thus, storage and marketing of grains, roots and tubers, and nuts and legumes are the major storage activities engage by the households.

Analysis of primary farm activities engaged by these rural households show that the major arable crops produced were rice, cassava and yam respectively. This finding is consistent with the findings of Nwibo and Aja (2013) who reported that most entrepreneurs in South East Nigeria who are into arable crop production grow cassava, rice, and yam with negligible production of maize, cocoyam and vegetable. 
Creative Commons User License: CC BY-NC-ND

Abstracted by: EBSCOhost, Electronic Journals Service (EJS),

Google Scholar, Journal Seek, Scientific Commons,

Food and Agricultural Organization (FAO), CABI and Scopus
Journal of Agricultural Extension

Vol. 23 (2) April, 2019

ISSN(e): 24086851; ISSN(Print); 1119944X

http://journal.aesonnigeria.org

http://www.ajol.info/index.php/jae

Email: editorinchief@aesonnigeria.org

Table 2: Primary agricultural activities

\begin{tabular}{lllll}
\hline Activities & $\%(\mathbf{n = 3 6 0 )}$ & $\begin{array}{l}\text { Nature } \\
\text { Activities }\end{array}$ & of & Mean \\
& & $(\bar{X})$ & \\
\hline Crop production & 64.4 & Rice & 88.8 & \\
& & Yam & 64.2 & \\
& Cassava & $166(71.6)$ & 47.5 \\
& Cocoyam & $6(2.6)$ & \\
& Maize & $24(10.3)$ &
\end{tabular}

Livestock

production
46.9

Goat \& sheep

Cattle

Poultry

Piggery

Rabbitory

Fishery

Mushroom

Vegetable

Firewood

Rope

Medicinal leaves
98.7

17 (11.0)

48 (11.2)

$11(7.1)$

$01(0.6)$

42 (27.3)
29.3

0. $(0.0)$

12 (66.9)

$9(50.0)$

$3(16.7)$

$5(27.8)$

Cassava

26 (53.3)

Rice

$20(42.5)$

Legumes

$8(17.0)$

Palm produce

13 (27.7)

33.87

51 (60.7)

$5(7.1)$

$46(54.8)$

38.1

$\begin{array}{lrlll}\text { Storage } & \text { and } 84(23.3) & & \text { Grains } & 51(60.7) \\ \text { marketing } & \text { of } & & \text { Palm products } & 5(7.1) \\ \text { agricultural } & & & \text { Roots and tubes } & 46(54.8) \\ \text { products } & & & \text { Nuts and legumes } & 25(29.8)\end{array}$

** Multiple responses obtained

Figures in parenthesis are in percentages

\section{Non-Farm Activities Engaged by the Rural Households and Average Amount Earned Per Month}

The tendency for people to change their occupation or employment at any point in time depends on certain conditions such as skills, level of education, available capital, land availability and personal needs. Empirical studies suggest that not much data are available to distinguish the various changes in livelihood activities engaged in by rural households over the years in Nigeria. 
Creative Commons User License: CC BY-NC-ND

Abstracted by: EBSCOhost, Electronic Journals Service (EJS), Google Scholar, Journal Seek, Scientific Commons,

Food and Agricultural Organization (FAO), CABI and Scopus
Journal of Agricultural Extension

Vol. 23 (2) April, 2019

ISSN(e): 24086851; ISSN(Print); 1119944X

http://journal.aesonnigeria.org

http://www.ajol.info/index.php/jae

Email: editorinchief@aesonnigeria.org

http://eoi.citefactor.org/10.11226/v23i2

The result as shown in Table 3 indicates that there have been changes in employment and occupation of the households in South-East Nigeria especially the rural non-farm sector.

Table 3 shows the various non-farm activities diversified into by the households. From the analysis the majority of the households $53.53 \%$ diversified into petty trading like sale of processed farm products, sale of fairly used clothes, restaurants, drinks/water, food vending etc, $31.31 \%$ engaged in storage and selling of commodities like grains, dry legumes and nuts. The result further reveals that $15.82 \%, 16.84 \%$ and $9.09 \%$ diversified their income activities into sale of landed property, agricultural wage labour and hire purchase respectively. However, $19.52 \%$, $21.21 \% 13.46 \%$ and $28.28 \%$ engaged in rental services, transportation (example taxis, motorcycle and tri-cycle business), craftsmanship and civil/public service works respectively. These changes in employment were mainly in the rural non-farm sector. The rural non-farm sector represents micro-small enterprises which is the product of economic growth and development in the rural communities. This includes numerous activities in agro-enterprises, agro-processing, small-scale manufacturing industrial, trade, skilled and unskilled services and other opportunities that exist in the rural areas.

Diversification into non-farm activities has been identified as insurance mechanism, as the associated losses may still be lower than those in farm activities (DARD, 2012). Analysis of data as shown in Table 3 revealed that storage, public/civil service, transportation, agricultural wage labour and sales of landed property are the major highly diversified areas. Justifying this result, Davis, Giuseppe and Zezza (2017) inferred that incomes from non-agricultural enterprises and non-agricultural wage labour have accounted for $53 \%$ of the total household income of rural households in Africa. Similarly, Ogbanje et al. (2015) corroborated that majority of rural households receive income from off farm sources and self employment activities. These activities, they noted were handicrafts, food processing, shop-keeping and trading on non-agricultural foods. Corroborating further, Batool (2017) stated that most diversified farm families diversify income livelihood mainly into off-farm, self-employment such as engaging in agricultural wage-labour, small manufacturing factories, construction and transportation as a means of shielding themselves from risk and the uncertainties of agricultural production. This finding is an indication that the majority of households in South East Nigeria maintain a good diversified income portfolio.

Table 3: Non-agricultural activities engaged by the rural households and average amounts earned per month

\begin{tabular}{lll}
\hline Type of Activities & Percentage $^{*}$ & $\begin{array}{l}\text { Average } \\
(\mathrm{A})\end{array}$ \\
\hline $\begin{array}{l}\text { Sales of landed property } \\
\text { Agric wage labour }\end{array}$ & 15.82 & 5,786 \\
Off farm processing \& petty & 16.84 & 889 \\
trading & 53.53 & 12,974 \\
Storage & & \\
Rental services & 31.31 & 8,889 \\
Transportation & 19.52 & 5,792 \\
Craftsmanship & 21.21 & 10,546 \\
Civil/public service & 13.46 & 8,903 \\
\hline
\end{tabular}

${ }^{\star}$ Multiple responses 
Creative Commons User License: CC BY-NC-ND

Abstracted by: EBSCOhost, Electronic Journals Service (EJS), Google Scholar, Journal Seek, Scientific Commons,

Food and Agricultural Organization (FAO), CABI and Scopus
Journal of Agricultural Extension

Vol. 23 (2) April, 2019

ISSN(e): 24086851; ISSN(Print); 1119944X

http://journal.aesonnigeria.org

http://www.ajol.info/index.php/jae

Email: editorinchief@aesonnigeria.org

\section{http://eoi.citefactor.org/10.11226/v23i2}

The majority of rural households in Southeast Nigeria have diversified their livelihood activities into non-farm. The households diversified into activities such as storage, public/civil service, transportation, agricultural wage labour and sales of landed property. This is indication that income from farm ventures alone is inadequate as such the households have to resort to non-farm activities as a way of augmenting whatever income is gotten from farm. Government should improve rural infrastructures like good roads network, rural electrification, potable water, telecommunication service, and affordable healthcare system since they are important for enhancing economic activities. Government should initiate policy for reducing risk and uncertainties inherent in agricultural activities in order to encourage farmers to remain in the business of farming.

\section{References}

Alkire, S., Apablaza, M. and Jung, E. (2014). Multidimensional poverty measurement for EU SILC countries. OPHI Research in Progress Series 36c. Oxford, University of Oxford.

Batool, S., Babar, A., Nasir, F. and Iqbal, Z.S. (2017). Income Diversification of Rural Households in Pakistan. Int J Econ Manag Sci, 6(6): 466. DOI: 10.4172/2162-6359.1000466

Benmehaia, M. A. and Brabez, F. (2016). Determinants of on-farm diversification among rural households: Empirical evidence from Northern Algeria. International Journal of Food and Agricultural Economics, 4(2), 87-99.

Briones, R. M. (2017). Transformation and diversification of the rural economy in Asia. IFAD Research Series 20, Philippine Institute for Development Studies.

Davis, B., Giuseppe, S.D. and Zezza, A. (2017). Are African households (not) leaving agriculture? Patterns of households' income sources in rural Sub-Saharan Africa. Food Policy, 67, 153174. https://doi.org/10.1016/j.foodpol.2016.09.018

Department of Agriculture and Rural Development (DARD) (2012). Increase your farm income: Diversification.

http://www.nibusinessinfo.co.uk/bdotg/action/detail?itemld=5000230724\&site=191\&type =R ESOURCES

Dev, T., Sultana, N. and Hossain, Md. E. (2016). Analysis of the Impact of Income Diversification Strategies on Food Security Status of Rural Households in Bangladesh: A Case Study of Rajshahi District. American Journal of Theoretical and Applied Business, 2(4), 46-56. doi: 10.11648/j.ajtab.20160204.13

Estruch, E. and Grandelis, I. (2013). Promoting economic diversification and decent rural employment towards greater resilience to food price volatility. Discussion Paper, Food and Agriculture Organization, Rome, Italy

Food and Agriculture Organization (FAO) (2017). The state of food and agriculture: Leveraging food systems for inclusive rural transformation. Rome: FAO Publication.

Igwe, P.A. (2013). Rural Non-farm livelihood diversification and poverty reduction in Nigeria. A

Ph.D thesis submitted to the School of Management (Plymouth Business School), University of Plymouth, Plymouth, United Kingdom.

Khatiwada, S.P., Deng, W., Paudel, B., Khatiwada, J.R., Zhang, J. and Su, Y. (2017). Household Livelihood Strategies and Implication for Poverty Reduction in Rural Areas of Central Nepal. Sustainability, 9, 612; doi:10.3390/su9040612 
Creative Commons User License: CC BY-NC-ND

Abstracted by: EBSCOhost, Electronic Journals Service (EJS), Google Scholar, Journal Seek, Scientific Commons,

Food and Agricultural Organization (FAO), CABI and Scopus
Journal of Agricultural Extension

Vol. 23 (2) April, 2019

ISSN(e): 24086851; ISSN(Print); 1119944X

http://journal.aesonnigeria.org

http://www.ajol.info/index.php/jae

Email: editorinchief@aesonnigeria.org

http://eoi.citefactor.org/10.11226/v23i2

Maniriho, A. and Nilsson, P. (2018). Determinants of Livelihood Diversification among Rwandan Households: The Role of Education, ICT and Urbanization. East Africa Research Papers in Economics and Finance, EARP-EF No. 2018:24

Nagler, P. and Naudé, W. (2017). Non-farm entrepreneurship in rural sub-Saharan Africa: New empirical evidence. Food Policy, 67, 175-191. doi: 10.1016/j.foodpol.2016.09.019

Nwibo, S.U. and Aja, O. (2013). Constraints to entrepreneurship and investment decisions among agribusiness investors in Southeast, Nigeria. International Journal of Small Business and Entrepreneurial Research, 1(4), 30-42.

Obinna, L. O. and Onu, S. E. (2017). Contributions of Rural Women Entrepreneurs in Non-Farm and Off-Farm Enterprises of Households Poverty Reduction in Abia State. Journal of Agricultural Extension, 21(3), 143-151.

Odoh, N.E. (2015). Effects of rural non-farm income diversification on poverty reduction level among farm households in South-east, Nigeria. Unpublished Ph.D Thesis submitted to the Department of Agricultural Economics, Management \& Extension, Ebonyi State University, Abakaliki.

Odoh, N.E. and Nwibo, S.U. (2016). Linkage effects of rural non-farm income diversification on poverty reduction among farm households in southeast Nigeria. International Journal of Science Research, 5(5), 350-355.

Ogbanje, E.C., Chidebelu, S.A.N.D. and Nweze, N.J. (2015). An Evaluation of Off-farm Work and Household Income among Small-scale Farmers in North Central Nigeria. Journal of Agriculture and Sustainability, 7(2), 227-244.

Olowa, O. W. (2012). Concept, Measurement and Causes of Poverty: Nigeria in Perspective. American Journal of Economics, 2(1): 25-36. doi: 10.5923/j.economics.20120201.04

Wan, J., Li, R., Wang, W., Liu, Z. and Chen, B. (2016). Income Diversification: A Strategy for Rural Region Risk Management. Sustainability, 8, 1064. doi:10.3390/su8101064

Williams, E. (2016). Alternatives Approaches to Reducing Poverty and Inequality: Existing Evidence and Evidence Needs. Proceedings of PPIW Evidence Workshop. 